\title{
Our economic crisis this day, ten years ago
}

\author{
Quan-Hoang Vuong \\ AISDL, Vuong \& Associates \\ ISR, Phenikaa University \\ July 24,2021
}

OSF Preprints; doi:10.31219/osf.io/be7d2

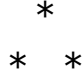

On July 24, 2011, I responded to several international newspapers regarding the state of the Vietnamese economy and the management capacity that the government could use to shore up the ailing economic apparatus.

I remember the first one I responded to is Wall Street Journal, titled "Vietnam Approves New Leadership" [1]. My opinion was that country's large trade deficit would not be fixed in the short term, and economic turmoil would be highly likely during PM Nguyen Tan Dung's second term. The calculation was then stated to have been based on the fact that

"problems have not been addressed adequately, and have not even appeared clearly on the new agenda."

And another well-known media was Agence France-Presse (AFP), titled "Le PM vietnamien Nguyen Tan Dung reconduit pour 5 ans" [2]. A verbatim quote from the paper is:

«La population supporte de moins en moins l'inflation. La pression sur le nouveau gouvernement sur ce front est énorme» [2].

All these predictions then turned out accurate and true. And it was very unfortunate that they cost the economy tens of billions of dollars in gross economic product and most probably another hundred billion dollars in unrealized opportunities. Of course, Mr. Nguyễn Tấn Dũng had not made it to his dream of becoming the next Party Chief and retired.

My comments came from economic calculations in a context. And the basis had been our joint book Kinh tế Việt Nam: Thăng trầm và đột phá [3] with Professor Phạm Minh Chính. More were provided to the economic analyses and reports later on, and one can now find some initial evaluations in [4-6].

Ten years later, things have changed much. 
Prof. Chính has become the Prime Minister of Vietnam and now had serious economic problems to handle, many of them caused by enormous disruption during the Covid-19 pandemic.

And right before his taking oath in front of the National Assembly on April 5, 2021, I had answered Tuoi Tre, delivering key messages to his new government and cabinet regarding economic lessons that history has taught us all over the tough years [7]. Naturally, inflation and macroeconomic imbalances had not been omitted.

I hope the economy can make it through these unprecedented times when Hanoi entered its second social distancing, facing the 4th wave of Covid-19. For our efforts to protect the nation's economic health effectively, learning from economic lessons from history will always be beneficial.

\section{References}

[1] Muoi NP. (2011). Vietnam Approves New Leadership. Wall Street Journal (July 24); Retrieved from: https://www.wsj.com/articles/SB100014240531119039999045764674212773800 $\underline{58}$ (accessed: July 24, 2021)

[2] Timberlake I. (2011). Le PM vietnamien Nguyen Tan Dung reconduit pour 5 ans. Agence France-Presse (July 24, 2011). Retrieved from La Presse (Canada): https://www.lapresse.ca/international/asie-oceanie/201107/26/01-4421045-lepm-vietnamien-nguyen-tan-dung-reconduit-pour-5-ans.php (accessed: July 24, 2021).

[3] Chính PM, Hoàng VQ. (2009). Kinh tế Việt Nam: Thăng trầm và đột phá. Nxb Chính trị Quốc gia, Hà Nội.

[4] Vuong QH. (2018). The financial economy of Viet Nam in an age of reform, 19862016. In: Routledge handbook of banking and finance in Asia (pp. 201-222). Routledge, London.

[5] Nguyen HKT, et al. (2019). The new politics of debt in the transition economy of Vietnam. Austrian Journal of South-East Asian Studies, 12(1), 91-110.

[6] Vuong TT, Semerák V, Vuong QH. (2019). The Vietnamese economy at the crossroads. In: Southeast Asia and the ASEAN economic community (pp. 91-143). Palgrave Macmillan, Cham.

[7] Kiên L, An N, Thanh L. (2021). Kỳ vọng Chính phủ mới: Tạo đột phá, đưa đất nước phát triển bền vững. Tuổi Trẻ (April 5). Retrieved from: https://tuoitre.vn/kyvong-chinh-phu-moi-tao-dot-pha-dua-dat-nuoc-phat-trien-ben-vung20210405082237431.htm (accessed: July 24, 2021). 